\title{
Trends in community structure on a Jamaican reef
}

\author{
Nina G. Andres ${ }^{1}$, Jon D. Witman ${ }^{2, *}$ \\ ${ }^{1}$ Northeastern University, Marine Science Center, East Point, Nahant, Massachusetts 01908, USA \\ ${ }^{2}$ Ecology and Evolutionary Biology Department, Box G-W, Brown University, Providence, Rhode Island 02912, USA
}

\begin{abstract}
A quantitative survey of species composition and diversity along depth gradients at Discovery Bay, Jamaica, in 1992 indicated that coral cover was $\leq 5 \%$ at all depths, except at $30 \mathrm{~m}$, where it attained $27 \%$. Percent cover by macroalgae ranged from 44 to $79 \%$ over the entire reef, with highest values between 5 and $20 \mathrm{~m}$ on the fore reef. Coral diversity increased with depth between a low at reef crest to a maximum of 0.96 (Brillouin's index, $\mathrm{H}$ ) at $30 \mathrm{~m}$. Total species diversity was highest at the back reef site (2.32). Coral cover at shallow depths $(1,5$, and $15 \mathrm{~m})$ was an order of magnitude lower than in 1982. Such striking changes in community structure over the past decade indicate how physical and biological perturbations (e.g. hurricanes, reduced urchin populations and fish grazing) have affected the reef.
\end{abstract}

KEY WORDS: Algae - Coral - Species diversity - Herbivores Hurricane Environmental perturbation

Patterns of reef community structure on the West Fore Reef at Discovery Bay, Jamaica have been described in a series of surveys of large-scale disturbances (Huston 1985, Liddell \& Ohlhorst 1986, 1987, 1992, Hughes et al. 1987. Hughes 1994). These disturbances include: Hurricane Allen in 1980, one of the strongest Caribbean storms of this century (Woodley et al. 1981. Kjerfve et al. 1986); mass mortality of the urchin Diadema antillarum Phillipi (Lessios et al. 1984, Hughes et al. 1985, Carpenter 1990); Hurricane Gilbert in 1988; and decimation of herbivorous fish populations from overfishing (Munro 1983, Picou-Gill et al. 1991).

Individual reef surveys through time represent 'snapshots' that can be used to assess the importance of various disturbances in community structure. The objective of this study was to quantify how the composition of the sessile reef community has changed as a result of these recent disturbances. Documentation of

-Addressee for correspondence depth-related trends was made on the Long Term Survey (LTS) buttress of the Discovery Bay West Fore Reef during February and March 1992

Materials and methods. Study site: The West Fore Reef of Discovery Bay is located on the north coast of Jamaica $\left(18^{\circ} 30^{\prime} \mathrm{N}, 77^{\circ} 20^{\prime} \mathrm{W}\right.$. Fig. 1). Depth-related biotic zonation of this reef has been thoroughly described (Goreau 1959, Goreau \& Goreau 1973, Lang 1974, Huston 1979, Liddell \& Ohlhorst 1987, 1992, Hughes 1994). The LTS reef, which lies within $200 \mathrm{~m}$ horizontal distance from study sites used by Huston in March 1977 (Huston 1979) and Liddell \& Ohlhorst in May 1980 and August 1982 (Liddell \& Ohlhorst 1987), was sampled using line transects (Loya 1978) placed at a depth of $1 \mathrm{~m}$ in the back reef, and at depths of 1,5 ,

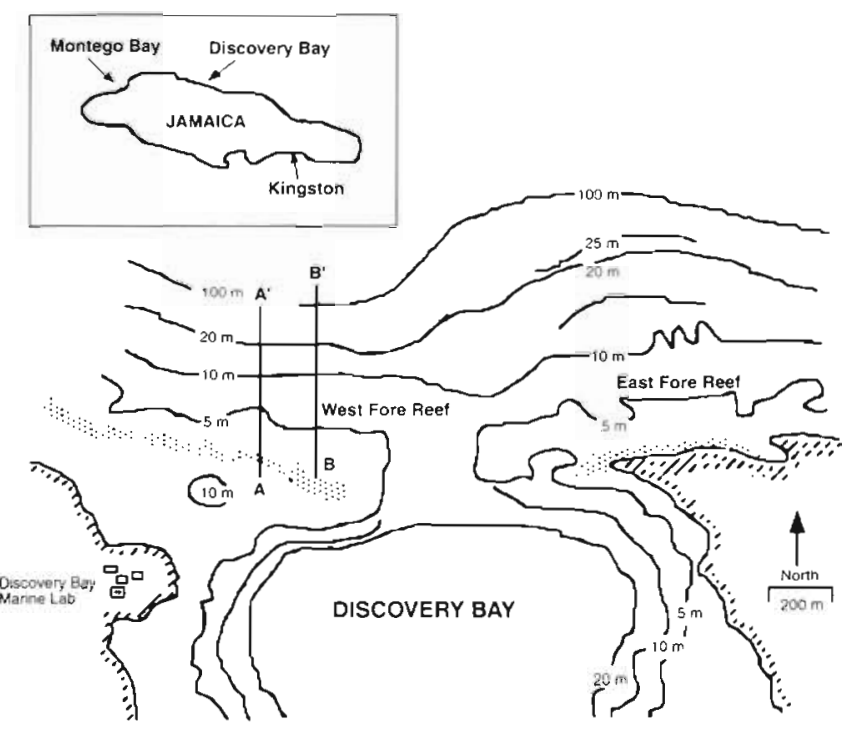

Fig. 1. Map of Discovery Bay, Jamaica (modified from Liddell $\&$ Ohlhorst 1987). Census sites in this study were located along the line A-A' Census sites from Huston (1985) and Liddell \& Ohlhorst (1987) are shown along line B-B' 
$10,15,20$, and $30 \mathrm{~m}$ in the fore reef. Transect lines were placed by an over-the-shoulder blind throw of a $25 \mathrm{~m}$ transect tape, marking the transect starting point The lines did not extend into any major sand channels. The sampling procedure consisted of extending the tape parallel to the depth contour. At 100 randomly located points along the transect tape each sessile organism greater than $5 \mathrm{~mm}$ in size beneath the transect point was identified and recorded. Reef substrates were also enumerated as sand or bare hard substrate. The procedure was repeated 4 times per depth yielding approximately 400 data points for each depth contour.

Statistical analyses: Assessment of community characteristics included measurements of species composition of sessile organisms, coral species abundance, percent cover of live macroscopic organisms, coral and total diversity ( $H_{i}$ Brillouin 1956) and species richness. Brillouin's index was used to measure diversity because the data set was a finite collection. (Pielou 1966). Community structure of sessile organisms was partitioned into 7 functional categories (Steneck \& Watling 1982, Morrison 1988) including coral (Scleractinia), macroalgae, coralline algae, filamentous algae, cnidarians (including hydrocorals and soft corals), sponges, living cover, and 2 substrate categories: sand and bare substrate. Macroalgae were grouped as Rhodophyta, Phaeophyta, and Chlorophyta. The percent composition of each species of coral was determined by dividing the number of colonies of an individual coral species by the total number of colonies of all coral species at a given site.

Significant differences $(p<0.05)$ between macroalgae composition, macroalgae percent cover, coral per- cent cover, total and coral diversity, and total and coral species richness as affected by depth were determined using ANOVA. A Bartlett's test was used to assess normality (data for coral percent cover and coral species number were log-transformed before the test). Based on pooled variance statistics from the ANOVA, Bonferroni tests were used to determine significant differences between means.

Results. Living cover: For all sites, except the back reef, the cumulative species richness curves (using total species) either leveled-off or increased only slightly, indicating that the sampling area was adequate. Living cover (all categories except sand and bare substrate) was dominated by algae (including macro-, coralline, and filamentous algae) with percent cover ranging from 75 to $94 \%$ over the entire reef; the lowest value was at $1 \mathrm{~m}$ and the highest at $30 \mathrm{~m}$ on the fore reef (Table 1). Coral cover did not exceed $5.0 \%$ at all depths except at $30 \mathrm{~m}$ where it reached $27 \%$, significantly higher than that at any other depth $(F=8.36$, $\mathrm{p}=0.0001$; Fig. 2). Macroalgae cover ranged from 44 to $79 \%$ over the entire reef with values at 10,15 , and $20 \mathrm{~m}$ in the fore reef significantly higher than those at the $1 \mathrm{~m}$ fore reef site $(F=11.48, p=0.0001$; Fig. 3). Rhodophyta comprised 51 and $54 \%$ of macroalgae cover at $1 \mathrm{~m}$ in the back and fore reefs, respectively; these values were significantly higher than those at all other depths $(F=44.41, p=0.0001 ;$ Fig, 4). Phaeophyta composition of macroalgae cover was significantly higher from 5 to $20 \mathrm{~m}$ in the fore reef than at all other depths (about 60\%; $F=45.65, p=0.0001$; Fig. 4). Chlorophyta coverage ranged from 5.5 to $18 \%$ of macroalgae composition over the reef, with its coverage at $1 \mathrm{~m}$ in the back reef significantly higher than in

Table 1. Mean percent community composition and diversity ( $H$ ) from 1 to $30 \mathrm{~m}$ on a Discovery Bay (Jamaica) reef as determined by line transects (mean $\pm \mathrm{SE}$ )

\begin{tabular}{|c|c|c|c|c|c|c|c|}
\hline \multirow[t]{2}{*}{ Category } & \multirow{2}{*}{$\begin{array}{l}\text { Back reef } \\
1 \mathrm{~m}(397)^{\alpha}\end{array}$} & \multicolumn{6}{|c|}{ Fore reef } \\
\hline & & $1 \mathrm{~m}(398)$ & $5 \mathrm{~m}(400)$ & $10 \mathrm{~m}(400)$ & $15 \mathrm{~m}(400)$ & $20 \mathrm{~m}(399)$ & $30 \mathrm{~m}(274)$ \\
\hline Corals & $1.5 \pm 0.5$ & $38 \pm 12$ & $2.3 \pm 0.7$ & $5.0 \pm 1.7$ & $3.5 \pm 1.2$ & $4.8 \pm 0.9$ & $27 \pm 7.6$ \\
\hline Cnidarians & $0.5 \pm 0.5$ & $0.5 \pm 0.3$ & $0.5 \pm 0.3$ & $0.5 \pm 0.3$ & $0.3 \pm 0.3$ & $0.3 \pm 0.3$ & $0.0 \pm 0.0$ \\
\hline Coralline algae & $20 \pm 3.5$ & $23 \pm 3.0$ & $7.8 \pm 1.0$ & $2.0 \pm 0.4$ & $2.3 \pm 0.5$ & $1.0 \pm 0.6$ & $11 \pm 2.5$ \\
\hline Filamentous algae & $5.3 \pm 1.3$ & $1.8 \pm 0.3$ & $1.3 \pm 0.9$ & $1.3 \pm 0.6$ & $1.3 \pm 0.5$ & $1.8 \pm 1.2$ & $3.3 \pm 1.5$ \\
\hline Macroalgae & $50 \pm 2.5$ & $44 \pm 2.8$ & $70 \pm 2.9$ & $79 \pm 2.9$ & $74 \pm 4.5$ & $78 \pm 4.0$ & $52 \pm 8.0$ \\
\hline Sponges & $0.0 \pm 0.0$ & $0.1 \pm 0.9$ & $0.2 \pm 0.9$ & $0.3 \pm 0.3$ & $0.3 \pm 0.3$ & $0.3 \pm 0.3$ & $2.0 \pm 0.8$ \\
\hline Sand & $9.5 \pm 4.3$ & $0.0 \pm 0.0$ & $2.0 \pm 1.2$ & $5.0 \pm 1.7$ & $11 \pm 2.7$ & $6.5 \pm 2.7$ & $2.3 \pm 0.9$ \\
\hline Bare hard substrate & $9.3 \pm 1.8$ & $25 \pm 2.9$ & $14 \pm 1.5$ & $6.8 \pm 1.2$ & $6.8 \pm 1.1$ & $7.8 \pm 0.2$ & $3.5 \pm 1.7$ \\
\hline Living cover & $80 \pm 4.8$ & $75 \pm 2.9$ & $84 \pm 1.2$ & $88 \pm 1.7$ & $82 \pm 3.6$ & $86 \pm 2.7$ & $94 \pm 0.9$ \\
\hline Total species no. & 42 & 29 & 22 & 24 & 17 & 23 & 29 \\
\hline Coral species no. & 4 & 5 & 4 & 8 & 8 & 7 & 7 \\
\hline Total diversity $(H)^{b}$ & 2.32 & 1.84 & 1.81 & 1.63 & 1.57 & 1.30 & 1.88 \\
\hline Coral diversity $(H)^{b}$ & 0.09 & 0.34 & 0.21 & 0.67 & 0.50 & 0.67 & 0.96 \\
\hline
\end{tabular}




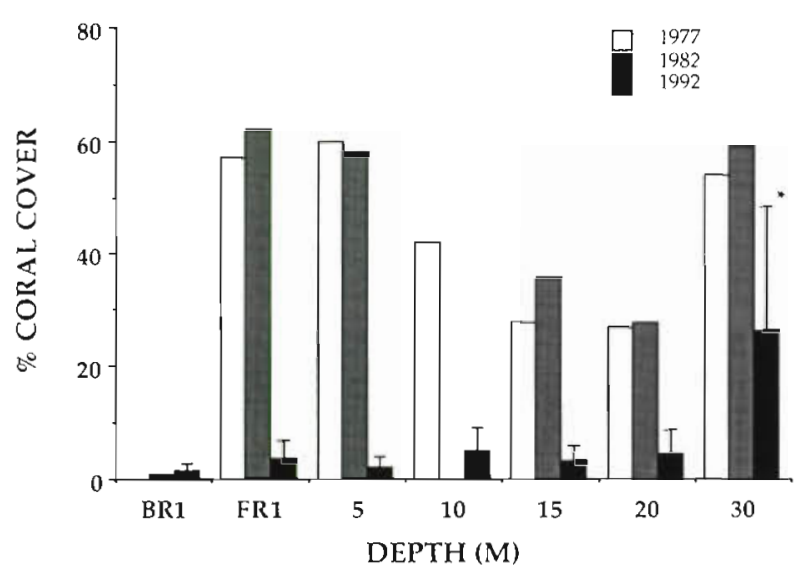

Fig. 2. Percent coral cover in 1977 (Huston 1985; fore reef only), 1982 (Liddell \& Ohlhorst 1987; all depths except $10 \mathrm{~m}$ on the fore reef), and 1992 (this study) on the West Fore Reef at Discovery Bay. BR refers to back reef, all other depths are on the fore reef (FR). Bars denote $95 \%$ confidence intervals. - Lower confidence interval is less than upper; coral cover at $30 \mathrm{~m}$ is significantly different from all other depths $(\mathrm{p}<$ $0.0001, \mathrm{df}=20$ )

the fore reef at $1 \mathrm{~m}$ depth only $(F=3.66, \mathrm{p}=0.012$; Fig. 4). Coralline algae coverage peaked at the reef crest (approx. 20\%,1 $\mathrm{m}$ depth, back and fore reefs) and at $30 \mathrm{~m}(11 \%)$ in the fore reef. Cover of filamentous algae was $5.3 \%$ or less at all depths.

Percent cover of sponges was low over the entire reef, reaching a peak of $2 \%$ at $30 \mathrm{~m}$ on the fore reef. Cnidarian coverage, which included the hydrocorals (Millepora alcicornis Linnaeus and $M$. complanata Lamarck) and soft corals (Erythropodium sp.), was $\leq 0.5 \%$ at all depths. Sand cover was highest in the

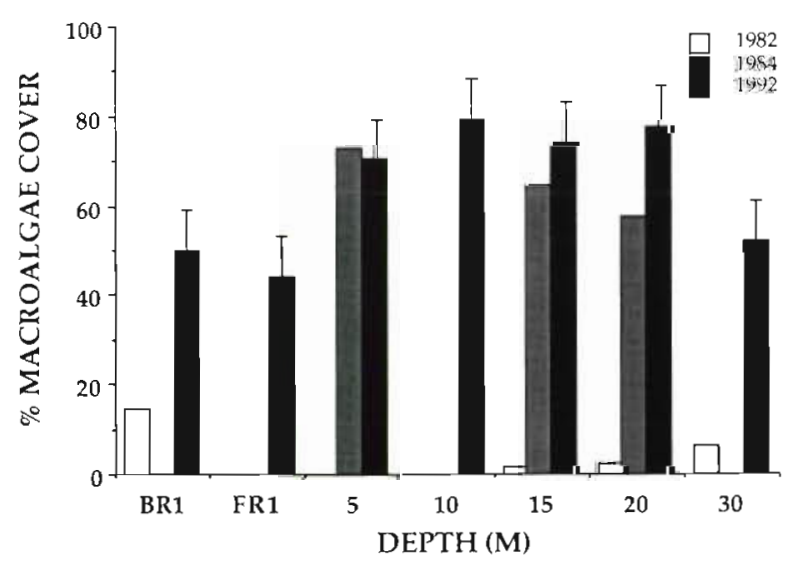

Fig. 3. Percent macroalgae cover in 1982 (Liddell \& Ohlhorst 1987; all depths except $10 \mathrm{~m}$ on the fore reef), 1984 (Liddell \& Ohlhorst 1986; 5, 15, $20 \mathrm{~m}$ only), and 1992 (this study) on the West Fore Reef at Discovery Bay. BR refers to back reef, all other depths are on the fore reef (FR). Bars denote $95 \%$ confidence intervals

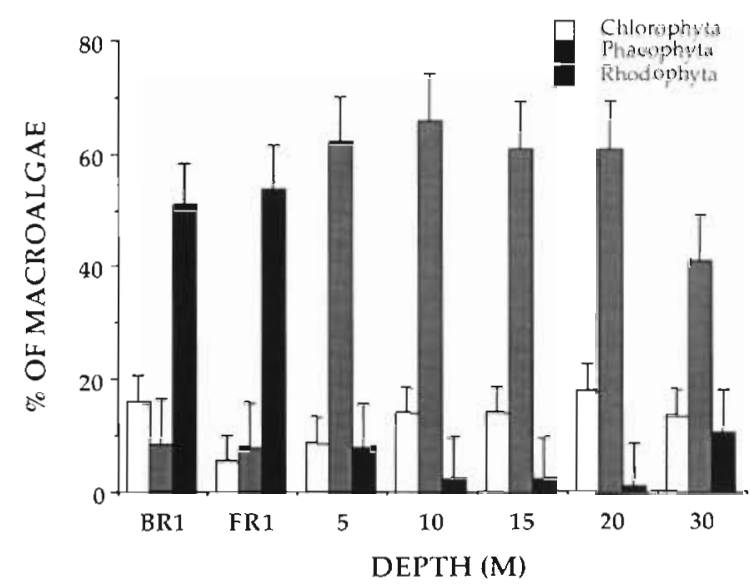

Fig. 4. Percent composition of macroalgae cover (Chlorophyta, Phaeophyta, and Rhodophyta) on the West Fore Reef at Discovery Bay. BR refers to back reef, all other depths are on the fore reef (FR). Bars denote $95 \%$ confidence intervals

back reef $(9.5 \%)$ and at intermediate depths (11\%, $15 \mathrm{~m}$ fore reef). Bare substrate was highest at the reef crest (25\%,1 $\mathrm{m}$ fore reef), but lower in deeper areas (3.5\%, $30 \mathrm{~m}$ fore reef)

A total of 16 coral species were found during the survey, with 5 corals (Agaricia agaricites Linnaeus, Diploria strigosa Dana, Montastrea annularis Ellis \& Solander, Porites astreoides Lesueur, and Siderastrea siderea Ellis \& Solander) composing $20 \%$ or more of the coral at one or more sites. Species replacement occurred in coral along the depth gradient. $P$. astreoides was dominant at the reef crest $11 \mathrm{~m}$ of the back and fore reef; 50 and $47 \%$, respectively), $A$. agaricites at intermediate depths $(5,15$, and $20 \mathrm{~m}$ fore reef; 33,29 , and $37 \%$, respectively), and $M$. annularis at $30 \mathrm{~m}(54 \%)$.

Diversity: Coral diversity increased with depth from the reef crest $(1 \mathrm{~m})$ to a maximum at $30 \mathrm{~m}$ (Fig. 5) where it was significantly higher than in the back reef and at $5 \mathrm{~m}$ in the fore reef $(F=4.52, \mathrm{p}=0.0048)$. Coral species richness directly correlated with coral diversity, and was significantly higher at $30 \mathrm{~m}$ than at any other depth $(F=6.50, \mathrm{p}=0.001)$.

Total diversity was significantly greater at the back reef site than at any other depth $(F=19.27, p=0.0001$; Fig. 5). Total species richness was also directly related to diversity values, peaking in the back reef and at $30 \mathrm{~m}$. Total species richness at $30 \mathrm{~m}$ was significantly greater than species richness from 5 to $20 \mathrm{~m}$ on the fore reef $(F=12.08, \mathrm{p}=0.0001)$.

Discussion. Community structure of the shallow West Fore Reef at Discovery Bay has changed over the past $15 \mathrm{yr}$ from being dominated by coral to being dominated by algae (Hughes 1989, Goreau 1992, Liddell \& Ohlhorst 1992, Hughes 1994). In our study, algae 


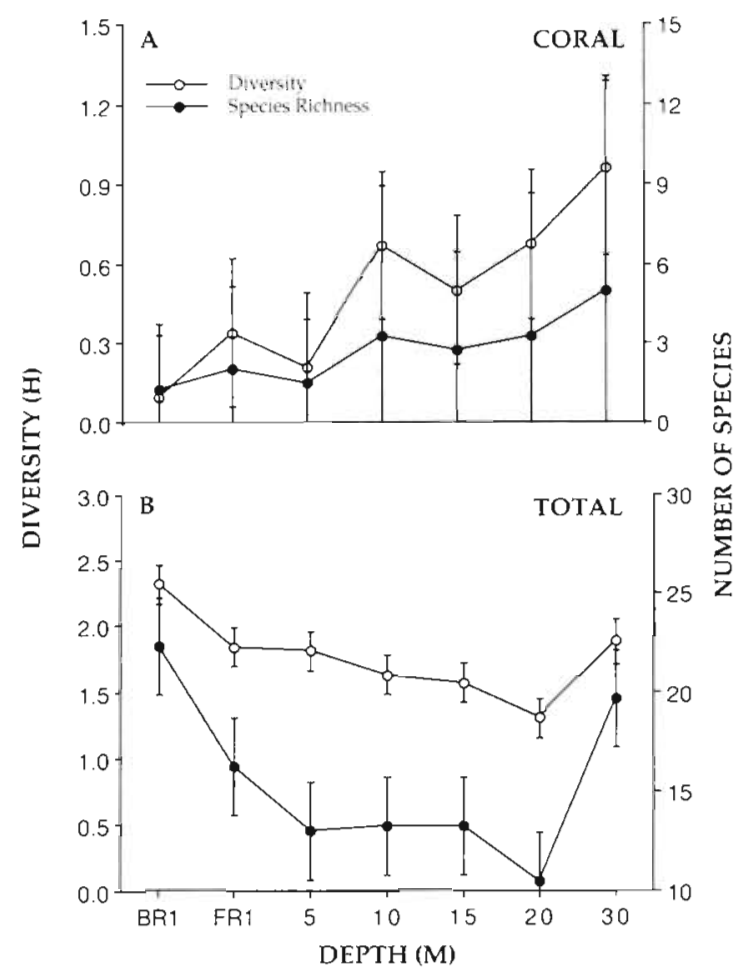

Fig. 5. (A) Relationship of coral diversity and species richness to depth on the West Fore Reef at Discovery Bay. (B) Relationship of total diversity and species richness to depth on the West Fore Reef at Discovery Bay. BR refers to back reef, all other depths are on the fore reef (FR). Bars denote $95 \%$ confidence intervals

comprises more than half of the live cover on the buttress. Coral composition is high $(27 \%)$ only at $30 \mathrm{~m}$, where Montastrea annularis is the predominant coral species. In $15 \mathrm{yr}$, coral has declined from $30-60 \%$ of reef coverage in 1977 (Huston 1985) to $5-25 \%$ in 1984 , after the Diadema antillarum die-off (Liddell \& Ohlhorst 1986), to $5-15 \%$ in 1986 (Gates 1990), to approximately $5 \%$ coverage above depths of $30 \mathrm{~m}$ in 1992.

The corals which currently inhabit the reef are ones that either survived Hurricane Allen and the subsequent rise in coral predation (Knowlton et al. 1990), are post-hurricane survivors, or early successional opportunists which were not competitively displaced by algae. However, because small corals are typically inferior substrate competitors with algae (Sammarco 1980, Liddell \& Ohlhorst 1986), and algal cover has increased on the reef since 1983, it is likely that rates of successful recruitment of corals since Hurricane Allen have been extremely low.

In contrast to the decline in coral cover, the abundance of algae has increased. Although the initial decrease in coral cover occurred in 1980 from Hurricane Allen (Porter et al. 1981, Woodley et al. 1981), it was not until 1984, when the abundances of the grazer Diadema antillarum and herbivorous fish were both very low, that algae began to greatly increase in abundance. Liddell \& Ohlhorst (1986) found that within 1 yr after the mass mortality of the urchin $D$. antillarum on the West Fore Reef algal cover increased up to 4 times its initial level. In addition, reef algal composition has changed. Algae species which accounted for $<5.0 \%$ cover over the entire reef in 1982, have greatly increased in percent cover since then. For example brown algae species, which have been found to develop both chemical and morphological resistance mechanisms to herbivores (Dictyota sp., Norris \& Fenical 1982; Lobophora sp., Nicotri 1980; Sargassum sp., Brock 1979), now make up more than $70 \%$ algal composition of the fore reef. As urchin grazing pressure declined in 1983 from urchin mortality, macroalgae unpalatable to herbivorous fishes (but palatable to urchins) became more abundant. Hurricane Gilbert in 1988 probably contributed to the reduction of these algal populations. But, continued low urchin densities and reduced concomitant grazing after the hurricane resulted in the population's recovery.

A steady decline in herbivorous fish populations has resulted in reduced grazing pressure on algal populations. Documentation of fishing pressure on the West Fore Reef of Discovery Bay has shown that the reef is overfished, and that herbivorous fish populations have been declining for at least the past 15 yr (Munro 1983, Picou-Gill et al. 1991). Although it is difficult to quantify the effects of this type of impact, it has undoubtedly had a positive effect on algal abundances on the reef and should be considered in decisions regarding reef maintenance.

Areas of the reef with the highest algal abundance, and most exposed to hurricane disturbance, have the lowest diversity. Total species diversity is highest at both depth extremes of the study area: $1 \mathrm{~m}$ in the back reef and $30 \mathrm{~m}$ on the fore reef. Coral diversity, however, is high only at $30 \mathrm{~m}$. The high total and coral diversity at the $30 \mathrm{~m}$ site is probably a result of reduced competitive displacement (Porter 1972) and less hurricane impact than at shallow fore reef depths (5 to $20 \mathrm{~m}$ ). Hurricane induced mortality, fluctuations of water temperature, salinity, and wave action may account for lower abundance, small colony size, lower living cover of coral, and possibly lower coral diversity on the reef flat compared with the deep reef. At deeper sites, where variability in physical parameters are low, biological factors, such as specialization (Loya 1972) or lack of competitive superiority (Porter 1972, 1974), have a greater influence on community diversity.

As physical and biological disturbances may vary over a depth gradient, so might the effects of distur- 
bances vary from one reef lobe to another across a reef system. The LTS lobe on the West Fore Reef at Discovery Bay is one that may have suffered more from hurricane damage, and subsequent urchin population reduction, than other buttresses. The effects of large disturbances, such as Hurricanes Allen and Gilbert, the Diadema antillarum die-off, and heavy fishing pressure, however, are wide spread on the West Fore Reef and into Discovery Bay (J. Woodley pers. comm.). This indicates that such effects are neither localized nor isolated to a specific area on the reef.

The extent to which both physical and biological disturbances have contributed to changes in reef community structure at Discovery Bay are demonstrated in this and in previous reef surveys. The results of this study indicate that, whereas, acute disturbances (e.g. hurricanes, Acanthaster planci plagues, Diadema antillarum die-off) change community structure, chronic disturbances (e.g. fishing pressure and algal abundance) influence rate and direction of community recovery. It is likely that if $D$. antillarum and herbivorous fish densities had remained similar to pre-hurricane levels, then the marine benthos of the West Fore Reef at Discovery Bay would still be dominated by corals. However, the combination of both short- and long-term disturbances and overfishing have dramatically changed the reef, and the recovery of coral populations is not imminent.

Acknowledgements. We thank P. Ewanchuk for his assistance in reef censuses, B. C. Campbell and B. E. Mackey for statistical assistance and helpful advice. Comments and suggestions by R. Gates, T Klinger, N. Rodenhouse, J. Woodley, and 2 anonymous reviewers are also very much appreciated. Support was provided in part by the East/West Marine Biology Program. Northeastern University. We thank the Discovery Bay Marine Lab staff for logistical help. This is Discovery Bay Marine Laboratory contribution number 572 and Marine Science Center contribution no. 206.

\section{LITERATURE CITED}

Brillouin, L. (1956). Science and information theory. Academic Press, New York

Brock, R. E. (1979). An experimental study on the effects of grazing by parrotfishes and role of refuges in benthic community structure. Mar. Biol. 51: 381-388

Carpenter, R. C. (1990). Mass mortality of Diadema antillarum I. Long-term effects on sea urchin population-dynamics and coral reef algal communities. Mar. Biol. 104: 67-77

Gates, R. D. (1990). Seawater temperature and sublethal coral bleaching in Jamaica. Coral Reefs 8: 193-197

Goreau, T. F. (1959). The ecology of Jamaican coral reefs. I. Species composition and zonation. Ecology 40:67-90

Goreau, T. F, Goreau, N. I. (1973). The ecology of Jamaican coral reefs. II. Geomorphology, zonation, and sedimentary phases. Bull. mar. Sci. 23: 399-464

Goreau, T. J. (1992). Bleaching and reef community change in Jamaica 1951-1991. Am. Zool. 32: 683-695
Hughes, T P. (1989). Community structure and diversity of coral reefs: the role of history. Ecology 70:275-279

Hughes, T. P. (1994). Catastrophes, phase shifts, and large scale degradation of a Caribbean coral reef. Science 265 . $1547-1551$

Hughes, T P., Keller, B. D., Jackson, J. B. C., Boyle, M. J. (1985). Mass mortality of the echinoid Diadema antillarum in Jamaica. Bull. mar. Sci. 36: 377-384

Hughes, T P., Reed, D. C., Boyle, M. J. (1987). Herbivory on coral reefs: community structure following mass mortalities of sea-urchins. J. exp. mar. Biol. Ecol. 113: 39-59

Huston, M. (1979). A general hypothesis of species diversity. Am. Nat. 113(1): 81-101

Huston, M. (1985). Patterns of species diversity in relation to depth at Discovery Bay, Jamaica. Bull. mar. Sci. 37: 928-935

Kjerfve, B., Magill, K. E., Porter, J. W., Woodley, J. D. (1986). Hindcasting of hurricane characteristics and observed storm damage on a fringing reef, Jamaica, West Indies. J. mar. Res. 44: 119-148

Knowlton, N., Lang, J. C., Keller, B. D. (1990). Case study of natural population collapse: post hurricane predation on Jamaican staghorn corals. Smithson. Contr. Mar. Sci. 31: $1-25$

Lang, J. C. (1974). Biological zonation at the base of a reef. Am. Sci. 62: 272-281

Lessios, H. A., Robertson, D. R., Cubit, J. D. (1984). Spread of Diadema mass mortality through the Caribbean. Science 226: 335-337

Liddell, W. D., Ohlhorst, S. L. (1986). Changes in benthic community composition following the mass mortality of Diadema at Jamaica. J. exp. mar. Biol. Ecol. 69: $271-278$

Liddell, W. D., Ohlhorst, S. L. (1987). Patterns of reef community structure, North Jamaica. Bull. mar. Sci. 40: 311-329

Liddell, W. D., Ohlhorst, S. L. (1992) Ten years of disturbance and change on a Jamaican fringing reef. Proc. 7 th int. Coral Reef Symp. 1: 144-150

Loya, Y. (1972). Community structure and species diversity of hermatypic corals at Eilat, Red Sea. Mar. Biol. 13: 100-123

Loya, Y. (1978). Plotless and transect methods. In: Stoddart, D. R., Johannes, R. E. (eds.) Coral reefs: research methods. UNESCO, Paris, p. $197-217$

Morrison, D. (1988). Comparing fish and urchin grazing in shallow and deeper coral reef algal communities. Ecology 69: $1367-1382$

Munro, J. L. (1983). Caribbean-coral reef fishery resources. International Center for Living Aquatic Resources Management, Manila

Nicotri, M. E. (1980). Factors involved in herbivore food preference. J. exp. mar. Biol. Ecol. 42: 13-26

Norris, J. N., Fenical, W. (1982). Chemical defense in tropical marine algae. In: Rutzler, K., Macintyre, I. G. (eds.) The Atlantic Barrier Reef ecosystem at Carrie Bay Cay Belize, Vol. 1. Structure and communities. Smithson. Contr. mar. Sci. 12: 417-431

Picou-Gill, M., Woodley, J. D., Miller, M., Sary, Z., Van Barneveld, W., Vatcher, S., Brown, D. (1991). Catch analysis at Discovery Bay, Jamaica: the status of an artisanal fishery. Gulf and Caribbean Fisheries Institute, Nassau

Pielou, E. C. (1966). The measurement of diversity in different types of biological collections. J. theor. Biol. 13: 145-163

Porter, J. W. (1972). Patterns of species diversity in Caribbean reef corals. Ecology 53: 745-748

Porter, J. W. (1974). Community structure of coral reefs on opposite sides of the Isthmus of Panama. Science 186: $543-545$ 
Porter, J. W., Woodley, J. D., Smith, G. J., Neigel, J. E., Battey, J F., Dallmeyer, D. G. (1981). Population trends among Jamaican reef corals. Nature 294: 249-250

Sammarco, P. W. (1980). Diadema and its relationship to coral spat mortality: grazing, competition, and biological disturbance. J. exp. mar. Biol. Ecol. 45: 245-272

Steneck, R. S., Watling, L. (1982). Feeding capabilities and limitation of herbivorous molluscs: a functional group

This note was submitted to the editor approach. Mar. Biol. 68: 299-319

Woodley, J. D., Chornesky, E. A., Clifford, P. A., Jackson, J. B. C., Kaufman, L. S., Knowiton, N., Lang, J. C., Pearson, M. P., Porter, J. W., Rooney, K. W., Rylaarsdam, K. W., Tunnicliffe, V. J., Wahle. C. M., Wulff, J. L., Curtis, A. S. G., Dallmeyer, M. D., Jupp, B. P., Koehl, M. A. R., Neigel, J., Sides, E. M. (1981). Hurricane Allen's impact on Jamaican caral reefs. Science 214: 749-755

Manuscript first received: November 13, 1992 Revised version accepted: December 2, 1994 